Article type : Review Article

\title{
Endothelial colony forming cells and proangiogenic cells: clarifying definitions and their potential role in mitigating acute kidney injury
}

\author{
David P. Basile ${ }^{1}$, Jason A. Collett ${ }^{1}$ and Mervin C. Yoder $^{2}$ \\ Department of Cellular \& Integrative Physiology ${ }^{1}$ and the Department of Pediatrics ${ }^{2}$ \\ Indiana University School of Medicine
}

Short title: Endothelial dysfunction and cell therapy in AKI

Correspondence to:

David P. Basile, Ph.D

Department of Cellular \& Integrative Physiology

Indiana University School of Medicine

635 Barnhill Drive, Med Sci 334

Indianapolis, IN 46202

USA

Email: dpbasile@iupui.edu

\begin{abstract}
Acute kidney injury (AKI) represents a significant clinical concern that is associated with high mortality rates and also represents a significant risk factor for the development of chronic kidney disease (CKD). This article will consider alterations in renal endothelial function in the setting of AKI that may underlie impairment in renal perfusion and how inefficient vascular repair may manifest post-AKI and contribute to the potential transition to CKD. We provide updated terminology for cells previously classified as "endothelial progenitor" that may mediate vascular repair such as pro-angiogenic cells and endothelial colony forming cells. We consider how endothelial repair may be mediated by these different cell types following vascular injury, particularly in models of AKI. We further
\end{abstract}


summarize the potential ability of these different cells to mitigate the severity of AKI, improve perfusion and maintain vascular structure in pre-clinical studies.

Key Words: Rarefaction, Angiogenesis, Ischemia, Fibrosis, Inflammation

\section{Background}

Acute kidney injury (AKI) represents a significant and growing clinical concern, which affects approximately $5 \%$ of hospitalized patients and is associated with high morbidity and mortality rates. AKI is defined as a rapid loss of renal function occurring over the course of hours or days and is primarily caused by impaired renal blood flow, nephrotoxicity or sepsis leading to ischemic or hypoxic damage ${ }^{1}$. In addition, AKI is associated with injury to the renal parenchyma, particularly tubular epithelial cells, but also vascular and interstitial cells. Repair mechanisms in the kidney typically mediate recovery of renal function and structure, which is observed in most surviving patients. However, it is now recognized that patients who have recovered from AKI are at increased risk for the development of either chronic kidney disease (CKD) or end-stage renal disease (ESRD) ${ }^{2-4}$. This may result from repair processes following AKI that are either incomplete or maladaptive, predisposing the development of renal fibrosis ${ }^{2}$.

\section{Impaired perfusion in acute kidney injury}

In animal models of acute kidney injury such as ischemia-reperfusion, there is typically an impairment in renal blood flow associated with lost renal function and tissue damage ${ }^{5}$. In models of sepsis, AKI may or may not occur in the presence of reduced renal blood flow, and this has been an area of some controversy ${ }^{6}$. The use of contrast media is another significant risk factor predisposing AKI. Contrast media is thought to promote vasoconstriction of pericytes, leading to an exacerbation of hypoxia in the renal medulla ${ }^{7}$. 
Regardless of effects on total renal blood flow, it is thought that heterogeneous disturbances in microvascular flow patterns are likely evident in AKI of various etiologies ${ }^{6}$. Such impairment at the microvascular level disrupts perfusion particularly in the renal medulla and is considered to be a significant reason why parenchymal cells in this region (primarily S3 proximal tubule cells) are the most severely affected in these models ${ }^{7}$. Recent reviews have highlighted how impairment of renal microvascular function is of central importance in both initiating and predicting the severity of AKI and have called for development of new methods to better evaluate renal perfusion in susceptible patients ${ }^{6}$. A better appreciation for the complicated nature of endothelial dysfunction in the setting of AKI can be obtained from a number of comprehensive review articles both by us ${ }^{5,8}$ as well as other investigators ${ }^{9-11}$. For the purposes of this article, we wish to highlight central concepts regarding impaired vascular function in the development of acute kidney injury, implications for transition from acute to chronic kidney disease, and how these may relate to the potential use of endothelialtargeted cell-based therapies.

Reductions in renal blood flow (RBF) following ischemia or hypoxia have been thought to be due, in part, to rapid vasoconstriction, perhaps secondary to impaired proximal tubular sodium reabsorption and activation of tubular glomerular feedback ${ }^{1}$. However, if glomerular filtration rate (GFR) is reduced, sustained tubular glomerular feedback likely does not contribute to sustained vasoconstriction ${ }^{6}$. While activation of other vasoconstrictor pathways (e.g., sympathetic tone, angiotensin II, endothelin) or impairment of vasodilator pathways (e.g., prostacyclin, nitric oxide) have been suggested to reduce renal blood flow during AKI, the inability of vasodilators to reverse AKI suggests that these pathways may play only a modest (at best) contributory role to sustained loss of renal function ${ }^{8}$.

This article is protected by copyright. All rights reserved. 
In the last 10-15 years there has been considerable attention focused on the potential role of the post-glomerular peritubular capillaries contributing toward the development of AKI. These vessels subserve reabsorption of water and solute from the interstitium back into systemic circulation and are a characterized by low hydrostatic pressure. These vessels also deliver oxygen and nutrients to the renal tubular system and are in close apposition to these cells. Counter current flow in vasa recta allows for oxygen shunting in the renal medulla and development of an oxygen gradient producing a relatively hypoxic environment ${ }^{9}$.

Reductions in RBF can reduce GFR and reduce tubular metabolic work, but extreme impairment may further exacerbate renal hypoxia and can activate inflammatory and cell injury pathways in nearby S3 proximal tubule or thick ascending limb ${ }^{1,9,10}$. Peritubular capillary damage may contribute further to impaired perfusion and may predict the severity and duration of AKI. In studies of transplant patients receiving cadaveric grafts, renal biopsies obtained immediately post-perfusion demonstrated evidence of both endothelial and vascular smooth muscle damage as indicated by reduced von Willebrand factor staining and actin cytoskeletal disorganization. The degree of vascular damage in the immediate posttransplant period was predictive of reduced graft function in the subsequent 7 days of recovery ${ }^{12}$.

\section{Endothelial dysfunction as a contributor to AKI}

Molitoris and Sutton suggested that disturbances in microvascular flow in the kidney lead to the extension phase of $\mathrm{AKI}{ }^{13}$, in which tubular damage is exacerbated by events in the endothelium which may include endothelial swelling, increased expression of adhesion molecules and associated recruitment of various leukocyte populations. Endothelial leukocyte adhesion, activated in the setting of AKI, may result from increased exocytosis of Weibel-Palade bodies ${ }^{14}$ and an immediate enhancement of surface adhesion molecules such 
as P-selectin ${ }^{15-17}$ and ICAM-1 ${ }^{1,18,19} 19$ (Figure 1). Increased co-stimulatory factor expression is also observed on the surface of capillary endothelial cells and inhibition of B7-1 reduces monocyte infiltration in the ascending vasa recta in response to renal ischemia reperfusion ${ }^{20}$.

The initiating pro-inflammatory activity in the endothelium requires further investigation. Paracrine factors such as cytokines or other danger signals from stressed epithelium represent potential links between the epithelial and vascular compartments ${ }^{10}$. Endothelial responses may also directly result from ischemia by altering endothelial cytoskeletal structure, resulting in reduced endothelial cell-cell contact or cell-adhesion complexes $^{21}$. Mitochondrial damage following ischemia has been documented in peritubular capillaries and a recent study showed that a compound that targets mitochondrial cardiolipin attenuated endothelial mitochondrial damage and the development of inflammation following renal ischemia reperfusion ${ }^{22}$. Both ischemia and sepsis are known to induce glycocalyx shedding. The glycocalyx is considered an initial layer of endothelial barrier function, and its disruption may initiate downstream signaling cascades and increase access of leukocytes to endothelial adhesion molecules ${ }^{21,23}$. Loss of endothelial cell barrier function may also activate coagulation cascades, and potentially influence renal function by increasing interstitial edema and intra tubular pressure ${ }^{23}$.

Leukocyte adhesion may contribute to the development of vascular rouleaux, which manifest prominently within a few hours post-ischemia in rodent models of AKI ${ }^{1,10}$. Vascular congestion and rouleaux have also been described in dogs following renal I/R ${ }^{24}$ and in monkeys following LPS induced AKI ${ }^{25}$. Further, Solez et al., demonstrated significant intravascular leukocyte accumulation in 63 of 66 cadaver kidneys from patients with established AKI for greater than 24 hours ${ }^{26}$. 
Efforts to improve renal perfusion in acute kidney injury have historically been directed toward managing fluid volume and cardiac output. While increased vasomotor tone may reduce GFR in the initial development of AKI, renal vasodilators have been shown to lack efficacy in improving renal function in established $\mathrm{AKI}{ }^{27,28}$. We recently suggested that the failure of vasodilators to alleviate established AKI is based on the inability of such therapies to resolve vascular congestion/ inflammation and that potential treatments should target established endothelial/leukocyte interaction ${ }^{8}$. In support of this idea, retrograde hydrodynamic delivery of saline at high pressure into the post-glomerular vasculature of rats alleviated vascular congestion, improved capillary perfusion and resulted in more rapid recovery of serum creatinine following the establishment of AKI ${ }^{29}$.

\section{Effects of renal injury on peritubular capillary rarefaction and the AKI to CKD transition}

The degree to which effective endothelial repair influences chronic renal function and the long-term sequelae of AKI has also received significant attention in the last 10-15 years. Several reports indicate that peritubular capillary density is reduced permanently following AKI despite the apparent recovery of function following the initial insult. In rats and mice, there is a $30-50 \%$ reduction in capillary density following AKI, which is proposed to promote tissue hypoxia and activate pathways associated with the development of interstitial fibrosis 5 , 30,31 and may also contribute to the sensitivity of post-ischemic rats to develop hypertension ${ }^{32}$. Sustained capillary rarefaction has emerged as a potential common feature present in nearly all models of chronic renal injury associated with interstitial fibrosis ${ }^{33}$. Capillary rarefaction is present in human CKD of a variety of different etiologies and the loss of capillaries is strongly correlated with interstitial fibrosis ${ }^{34}$. Thus it is conceivable that impaired renal microvascular perfusion may represent a potential biomarker to predict the 
onset and severity of CKD. Chade and colleagues have demonstrated that CT imaging can be used to detect deficits in renal perfusion associated with vascular rarefaction using a swine model of renal artery stenosis ${ }^{35}$. Similarly, MRI techniques have shown promise to identify differences in renal perfusion patterns in patients with mild CKD vs. healthy control patients 36. These observations suggest novel imaging approaches could be used to measure impaired renal perfusion and identify patients at risk of progression.

While hypoxia secondary to vascular dropout appears to contribute to the development of renal fibrosis following AKI, there is clearly complex interplay involving multiple cell types that culminate in the AKI to CKD transition ${ }^{1,37}$. For example, in recent years, it has been suggested that pericyte detachment from damaged peritubular capillary endothelial cells trigger their activation to pro-fibrotic myofibroblasts representing the primary cell type contributing toward extracellular matrix $(\mathrm{ECM})$ production $^{38}$.

In addition, recent evidence supports the view that persistently damaged tubular epithelium contributes to the development of fibrosis (reviewed extensively in ${ }^{37,39,40}$ ). Interestingly, significant damage specifically in proximal tubule cells using a transgenic diphtheria toxin receptor transgenic mouse model was shown to result in persistent inflammation, activation of fibroblasts and interstitial fibrosis ${ }^{41}$. It is thought that dedifferentiated cells and/or cells which become arrested in G2/M phase of proliferation produce pro-fibrotic mediators such as TGF- $\beta$ or CTGF, interact within the interstitial environment and stimulate the production of $\mathrm{ECM}^{39,40}$.

The failure of epithelial cells to fully repair may represent a deficit of the tubular cell itself, however we suggest such failed recovery may also result from the lack of appropriate local perfusion secondary to capillary rarefaction. Indeed, Suzuki et al., demonstrated in a model of microembolism that hetergeneously damaged peritubular capillaries were in close apposition to areas of simplified epithelia and increased interstitial cell density ${ }^{42}$. Taken 
together the development of interstitial fibrosis in the AKI to CKD transition can be viewed as complex interaction of damaged vascular, epithelial and interstitial cell types, and the targeting of any of these pathways could be envisioned to promote more successful repair and improved long-term outcomes ${ }^{2}$.

\section{Causes of capillary rarefaction following renal injury}

If reduced peritubular capillary density represents a significant contributor toward progression of $\mathrm{CKD}$, then an understanding of the pathophysiological loss of capillary density following an injury may help identify potential therapeutic strategies. The cause of capillary rarefaction is not firmly established, but it likely involves endothelial mesenchymal transition (EndoMT), combined with a relative lack of compensatory endothelial proliferation $^{43,44}$ (Figure 2). These activities may result from a combination of a reduced angiogenic environment and trophic support from surrounding tubules or pericytes ${ }^{45-47}$. Goligorsky and his colleagues have suggested inhibition of eNOS could trigger EndoMT ${ }^{48}$ and that in the setting of vascular stasis, reduced shear stress may be a trigger for EndoMT and vascular rarefaction ${ }^{49}$. Patschan et al., suggested that EndoMT may result from endothelial cytoskeletal alterations in response to ischemia, which reduces $\alpha$-tubulin expression and is associated with impaired endothelial cilia function ${ }^{44}$. Interestingly, in animal models of AKI, EndoMT and rarefaction of capillaries is sustained despite ongoing renal tubular repair and recovery of renal function. For example, our laboratory demonstrated evidence of EndoMT for up to 7 days following I/R in rats, while Ehling et al., demonstrated the nadir of capillary density was not reached until approximately 14 days following $\mathrm{I} / \mathrm{R}$, a time point well beyond the normal re-establishment of plasma creatinine to normal values 50,51 .

This article is protected by copyright. All rights reserved. 
We have suggested that sustained capillary rarefaction may be attributable to the lack of resident renal endothelial progenitor activity, representing the basis for modest EC proliferation and sustained rarefaction observed following injury ${ }^{50}$ (described further, below). Interestingly, VEGF121 treatment post I/R prevented capillary rarefaction by attenuation of EndoMT but did not influence kidney endothelial proliferation ${ }^{43}$. Therefore, given the sustained duration of EndoMT process contributing to capillary loss following recovery from acute injury, a critical therapeutic window may be available to treat patients recovering from AKI to improve capillary survival and long term renal function.

Taken together, the issues highlighted above indicate a need for therapeutic approaches to address endothelial function to treat both the acute as well as the chronic vascular damage resulting from AKI. The remainder of this article will focus primarily on the potential role of stem and progenitor cells targeting endothelial function and the potential therapeutic applications of these cells in the setting of acute kidney injury.

\section{Defining cells types with potential for endothelial repair potential}

Numerous studies invoking a role for endothelial progenitor cells (EPC) in renal vascular repair in both acute and chronic kidney disease have been published. However, the field has been hampered by inconsistent definitions and different methodologies used to isolate or identify various cell types classified as EPCs. Because of the variety of different cell types used in these studies, we endorse previous suggestions to abandon the term "endothelial progenitor cell" in favor of more precise terminology to allow for better interpretation and comparison of the results from different studies ${ }^{52}$. In general, cells with particular relevance to angiogenic repair can be classified into two broad categories as either hematopoietic or endothelial in origin and these distinctions are described in greater detail below.

This article is protected by copyright. All rights reserved. 
Historically, most studies have referred to EPCs as bone marrow-derived cells, which express cell surface markers common to endothelial cells and may mediate pro-angiogenic or vascular repair activity ${ }^{53}$ (Figure 3). Several populations of cells have been described and characterized by the nature of their biological source, isolation procedure and the presence of various cell surface markers which provide insight into their origin. Hematopoietic stem cells (HSC) give rise to multiple lineages of myeloid and lymphoid cells, many of which display pro-angiogenic activity ${ }^{54-57}$. Therefore different selection criteria may lead to isolation of upstream progenitors with the potential to differentiate into more terminally differentiated cells which may modulate vascular injury. While HSC differentiate into a variety of different myeloid and lymphoid populations, advances in confocal imaging to improve spatial localization of transplanted cells ${ }^{58}$ and the use of lineage specific reporter transgenic murine models ${ }^{59-61}$ or analysis of epigenetic regulation in endothelial cells ${ }^{62}$ has eliminated any evidence that these cells are capable of differentiating into endothelial cells. Nevertheless, their involvement in processes such as vascular remodeling ${ }^{63-65}$ make them particularly relevant in understanding potential effects in the setting of acute kidney injury.

Early outgrowth/ CFU Hill cells: As originally described, EPCs are isolated from either low density mononuclear cells or CD34+ or CD133+ enriched cells, which are cultured for several days on fibronectin coated plates. The cells express markers of endothelial cells such as CD31, CD105, CD144, CD146, vWF and KDR ${ }^{66}$. These cells have subsequently been referred to as "early outgrowth" cells or colony forming unit Hill (CFU-Hill) cells ${ }^{67-70}$. The cells have generally been shown to be effective at promoting vascular repair via paracrine secretion of proangiogenic molecules in preclinical models of vascular repair where they typically improve or hasten remodeling ${ }^{70}$. These cells are now all recognized to be various stages of hematopoietic cells with proangiogenic potential ${ }^{70-72}$. 
Hematopoietic pro-angiogenic cells: Putative endothelial progenitor activity from cells isolated based on their expression of surface markers of CD34, CD133 and the VEGFR2 (KDR) has been reported ${ }^{68}$. Many studies report that these cells augment angiogenic repair in vascular injury models ${ }^{67,73,74}$ leading to the suggestion that these cells contain endothelial progenitor activity. However, careful examination has demonstrated that CD34/CD133/VEFR2 cells possess hematopoietic colony forming activity ${ }^{75,76}$. While neither the CD34/CD133/VEFR2 expressing cells or CFU-Hill cells have been shown to become bone fide endothelial cells by incorporating into the endothelial layer of a repaired vessels, the ability of the CD34/CD133/VEFR2 expressing cells to promote vascular repair, and the ability to isolate these circulating cells from blood has suggested that these may serve as a potential biomarker for overall cardiovascular risk ${ }^{77,78}$.

Circulating Angiogenic Cells: This term has been applied to a variety of hematopoietic stem and progenitor cells that display the capacity to secrete proangiogenic factors that participate via paracrine mechanisms to promote vascular repair and regeneration. However, this term may more broadly include non-hematopoietic cells present in the circulation such as rare endothelial colony forming cells (cECFC) or even mesenchymal cells. In essence any cell that can circulate in the bloodstream that produces proangiogenic molecules may be generally referred to as a circulating angiogenic cell; thus, the term lacks specificity and as such fails to provide the reader with clarity about the cell type being examined ${ }^{52,79}$

Myeloid angiogenic cells: This term represents a population of cells derived from peripheral blood derived cultures which express markers of myeloid progenitor cells, monocytes, or macrophages, but do not express markers of hematopoietic stem and progenitor cells and do not proliferate significantly ex vivo ${ }^{80-82}$. Of interest, these cells do 
express potent angiogenic growth factors and participate in vascular remodeling and repair ${ }^{83}$. This term is a preferred choice for describing the non-ECFC types of angiogenic cells that participate in paracrine support of vascular repair according to a recent consensus statement. $^{40}$

Endothelial colony forming cells. This term identifies rare circulating viable endothelial cells that give rise to colonies of endothelial cells when peripheral blood cells are cultured in vitro $^{84,85}$. While most circulating endothelial cells are undergoing apoptosis or necrosis in the bloodstream $^{86}$, very rare viable cells possess this endothelial colony forming cell (ECFC) ability ${ }^{85}$. These cells have been isolated from human, baboon, rhesus monkey, cow, sheep, dogs, pigs, and rabbit peripheral blood (reviewed in ${ }^{87}$ ). Human ECFC have been delivered in numerous animal models of human disease and display postnatal vasculogenic properties by making human blood vessels in all the models in which the ECFC are delivered directly into ischemic or injured tissue ${ }^{88,89}$. When ECFC are delivered intravascularly into injured animals, little engraftment has been observed and the protective effects to enhance vascular recovery has been demonstrated to reside in secreted molecules released by the ECFC or contained in their exosomes ${ }^{90,9119}$.

\section{A variety of different cell types influence endothelial responses to renal injury}

Based on the description above, we sought to classify studies based on whether the cells of interest could be identified as either pro-angiogenic cells, endothelial colony forming cells (ECFC) or endothelial cells (EC). The term pro-angiogenic cells is meant to convey any cell of hematopoietic origin with potential vasculogenic activity and would therefore encompass cells such as early outgrowth "endothelial" cells (eOEC) or myeloid angiogenic cells. In some cases, we were unable to be sure which of these categories was isolated by the 
authors of the numerous papers that have delivered "EPC" into murine models of AKI and therefore categorized the cell type as indeterminate (Table 1). It is of interest that exogenous delivery of both pro-angiogenic cells and ECFC possess protective activity in models of AKI.

Pro-angiogenic cells. Interest in bone marrow-derived pro-angiogenic cells arises from studies demonstrating the localization of cells expressing both hematopoietic and endothelial markers at sites of vascular injury as well as studies indicating that exogenously administered pro-angiogenic cells influence outcomes in various models of vascular injury. Early outgrowth EPC or blood derived CD34+ cells home to sites of injury, improve perfusion and stimulate angiogenesis in models of ischemia of the myocardium or hindlimb 80, 92 . The basis for the pro-angiogenic environment created by BM-derived cells is thought to be the production of factors such as VEGF, HGF or G-CSF ${ }^{53,92-94}$. Pro-angiogenic cells have been shown to limit neointima formation and improve arterial reactivity following aortic balloon injury ${ }^{93}$. Since these cells do not differentiate into endothelial cells, the current view is that the pro-angiogenic environment created by these cells activates proliferation and migration of tissue resident HPP-ECFC (high proliferative potential-endothelial colony forming cells) to facilitate recovery from injury (Figure 4).

In kidney, selective injury to the renal vascular endothelium via infusion of concanavalin A into the renal artery was shown to induce homing of bone marrow derived CD34+/Flk1+ positive cells, which were referred to as EPCs. Mobilization of these cells was evident within 3 hours in the blood and infiltration into the kidneys established within 3-5 days ${ }^{95}$. Mediators of this homing activity have been suggested to include secretion of cytokines such is IL-8, G-CSF or GM-SCF. Injury induced up-regulation of the chemokine SDF-1 was shown stimulate homing of pro-angiogenic cells in CXCR4 dependent fashion 
following I/R injury in mice ${ }^{96}$, while others have suggested that the up-regulation of adhesion molecules on the surface of damaged endothelial cells may promote homing of these cells to injured kidney ${ }^{97}$. Finally, uric acid, which is produced abundantly by ischemic kidney and is elevated in pigs with renal artery stenosis ${ }^{98}$, has also been suggested as a potential homing signal, since administration of a uricase inhibitor blunted the mobilization of cells into mouse kidney following $\mathrm{I} / \mathrm{R}^{99}$.

Bone marrow derived pro-angiogenic cells appear to influence renal vascular function in the setting of AKI (Figure 5). Patschan and colleagues demonstrated increased levels of "EPC"-activity, defined as c-Kit+/Tie-2+ cells in a mouse model of ischemic preconditioning. When these cells were isolated from preconditioned kidneys, they conveyed protection in recipient mice subjected to I/R injury ${ }^{100}$. Other studies using exogenous proangiogenic cells (derived from isolated and cultured mouse mononuclear cells), demonstrated similar effects on protection from renal injury, but did not directly assess vascular function 101, 102. Recently, administration of these cells was shown to attenuate peritubular capillary rarefaction post I/R, in part by inhibition of EndoMT ${ }^{44}$.

Other preparations of hematopoietic stem cells with putative pro-angiogenic activity have led to conflicting results on the outcome of renal injury. For example, Burger et al., isolated CD133+ cells from human cord blood, of which up to 83 percent of the cells were CD34+, 98 $\%$ were CD45+, while only $26 \%$ were KDR positive. Administration of these cells to NOD SCID mice following renal $\mathrm{I} / \mathrm{R}$ worsened changes in serum creatinine, tubular damage and promoted inflammation, while the cells did not home to the kidney ${ }^{103}$. These studies suggest that isolation based on CD133+ alone includes diverse hematopoietic progenitor cells that increases the inflammatory response to AKI rather than promoting protection. 
In contrast, Li et al., studied HSPC from adult volunteers pretreated with G-CSF to promote HSC mobilization. Mobilized CD34+ cells enriched from peripheral blood mononuclear cells by magnetic separation were primarily CD45+ and only a small percentage expressed CD14, CD133, CD146, CD31 or KDR. However transplanted cells homed to kidney 24 hours following renal ischemia reperfusion injury, and improved renal function and survival in NOD SCID mice. Many cells were localized in the perivascular area between 2-3 days post-injury and expressed markers of endothelial cells such as human hCD31 or KDR, however these exogenous cells were essentially absent by 7 days post-injury ${ }^{104}$. Interestingly, in human transplant patients, a transient elevation in recipient CD34+ cells were observed frequently along the peritubular capillary lining within 2 weeks of ischemia, while no evidence of recipient cells were observed in the vasculature after 35 or 73 days ${ }^{105}$. Taken together, these data support the view that transient homing of bone marrow derived pro-angiogenic cells migrate to areas of vascular injury and may stimulate remodeling, but these cells do not stably integrate into the vasculature, suggesting they do not act as de facto progenitor cells.

Despite this, these cells may stimulate endothelial cell proliferation and migration, and have been shown to induce angiogenic branch formation in vitro and in vivo ${ }^{53,92-94}$. These cells are thought to subserve an important homeostatic function. Goligorsky and colleagues have articulated that the concept of "EPC incompetence", based on studies demonstrating that the number or activity of bone marrow derived pro-angiogenic cells is impaired in patients with increased cardiovascular risk factors. Vascular impairment in these patients can be thought of as a result of reduced activity or mobilization of these cells to maintain vascular homoeostasis, a viewpoint consistent with the increased susceptibility of patients with CKD to develop AKI ${ }^{106}$.

This article is protected by copyright. All rights reserved. 


\section{Endothelial colony forming cells}

As described above, endothelial colony forming cells (ECFC), often referred to as "late outgrown endothelial cells" have been isolated following culture of blood cells on collagen following removal of non-adherent monocytes and subsequent expansion ${ }^{53}$. ECFC express classic markers of endothelial cells including CD31 and VEGFR2, as well as other markers. In contrast to hematopoietic pro-angiogenic cells, ECFCs do not express markers such as CD45 and are capable of forming and stably integrating into functional vessels in vivo 53,55 , 107.

ECFCs can be classified based on their proliferative potential in single cell colony forming assays, in which high proliferative potential (HPP) ECFC will form large colonies $(>10,000)$, while low proliferative potential (LPP) ECFC form small colonies $(<2000)$. ECFCs can be isolated and expanded from blood of humans and other large species, but cannot be isolated from blood of rodents ${ }^{55}$. However, ECFC can also be isolated from tissues of a variety species, including rodents. This observation has led to the hypothesis that a cooperative interaction between infiltrating pro-angiogenic cells of hematopoietic origin work to provide a trophic environment to stimulate local ECFC progenitor activity to stimulate vascular repair ${ }^{108}$ (Figure 4). Interestingly, our data in rats failed to demonstrate evidence of HPP-ECFC populations in kidney; rather we found only evidence of cells capable of forming small colonies, i.e., low proliferative potential ECFC ${ }^{50}$. These observations combined with the lack of BrdU+ capillary endothelial cells following renal I/R ${ }^{43}$ suggest that a low degree of endogenous ECFC activity may contribute to impaired recovery and maintenance of vascular rarefaction following AKI (Figure 2).

Because ECFC represent true endothelial progenitors, there is considerable interest in exploiting these cells for potential therapeutic effects. Human cord blood represents one of the richest sources of HPP-ECFC ${ }^{85}$ and recent studies also demonstrate that iPS cells can be 
differentiated into highly active HPP-ECFC ${ }^{88}$. To date, the potential therapeutic benefit of ECFC has been less well studied in preclinical models of vascular impairment than hematopoietic pro-angiongenic cells. Nevertheless, ECFCs stimulate neovascularization in a hindlimb ischemia model ${ }^{109}$ and attenuate the development of pulmonary hypertension in a rat model of arrested alveolar development ${ }^{90}$

ECFC appear to effectively ameliorate the severity of injury in models of AKI (Figure 5), an observation gleaned initially from studies in which the influence of HUVEC administration was assessed in a model of I/R. HUVEC rapidly expand in culture and contain a significant population of HPP-ECFC ${ }^{108}$. In these studies, systemic infusion of HUVEC in athymic rats following I/R injury significantly improved capillary flow rates as observed by video microscopy ${ }^{110,111}$. HUVEC infusion also resulted in a significant protection against the loss of renal function (e.g., by serum creatinine) and tubular injury. Surrogate non-endothelial cells had no effect on I/R induced damage, but when cells overexpressed eNOS, there was an improvement in renal blood flow leading to the suggestion endothelial supplementation influenced AKI via the nitric oxide pathway ${ }^{102,103}$.

Recent results from Burger et al., support the suggestion that ECFC have renal protective properties. Using human cord-blood derived HPP-ECFC injected immediately following ischemia reperfusion, AKI was attenuated in SCID mice as assessed by creatinine, tubular necrosis, macrophage infiltration and oxidative stress ${ }^{112}$. In contrast to results obtained with bone marrow derived pro-angiogenic cells, ECFCs showed very little evidence of homing into the kidney. Similarly, our group recently demonstrated that rat pulmonary microvascular endothelial cells (PMVEC), which have a high level of HPP-ECFC, failed to home to the kidney but protected Sprague Dawley rats from I/R induced AKI ${ }^{19}$. In contrast, studies by 
Pang et al., demonstrated that a small number of EC/ECFC from isolated from human renal artery migrate into the renal peritubular region of SCID mice following severe I/R injury ${ }^{113}$, suggesting that the fate of transplanted EC/ECFC following kidney injury is not clearly understood.

It is of interest that low proliferative potential ECFC (from pulmonary artery) had no protective effect on ischemia reperfusion injury ${ }^{19}$, indicating that the protective effects are a function of the proliferative capacity of ECFC. Interestingly, Patschan et al., found only minimal protection from AKI by late outgrowth cells obtained from mouse peripheral blood and spleen ${ }^{114}$. These cells expressed markers of EC such as VE-cadherin, but since ECFC do not circulate in mice ${ }^{114}$, these cells likely had low proliferative potential relative to other studies demonstrating protective effects of ECFC.

The lack of homing of ECFC suggests that secreted factors may promote resistance to AKI. Exosomes derived from ECFC conditioned media improve renal function post ischemia and prevent endothelial injury to hypoxia in vitro ${ }^{112}$. ECFC derived exosomes contain a high level of microRNA486-5p which may mediate these protective effects by decreasing endothelial PTEN (Phosphatase and tensin homolog) and increasing Akt ${ }^{91}$. Other investigators have demonstrated microvesicles (MV) from conditioned media of human blood derived EC protected Wistar rats from AKI, while micro-vesicles derived from fibroblasts did not. Treatment of MV with Dicer or antimir 126 or 296 blocked the protective effect of microvessicles ${ }^{115}$. The authors proposed a so-called "horizontal transfer" of information of miRNA from micro-vesicles into the endothelium as the basis by which protection is mediated ${ }^{115,116}$. We recently demonstrated that rat PMVEC or conditioned media of human ECFC protected against early alterations in renal hemodynamics following ischemia reperfusion injury, by preventing the loss of renal medullary blood flow. Human ECFC 
conditioned media also prevented the immediate up-regulation of endothelial ICAM-1 and the rapid infiltration of T-lymphocytes into the kidney within hours of ischemia reperfusion 19

Despite protective effects of both bone marrow derived pro-angiogenic cells and ECFC in acute kidney injury, whether these strategies can be used to effectively reverse the rarefaction of vessels associated with AKI and prevent progressive CKD has not been explored. The paradigm of cooperative interaction ${ }^{108}$ (and Figure 4) highlights the role of local ECFC in the vascular repair response which could be stimulated by pro-angiogenic cell-treatment.

\section{Future Directions}

We hypothesize that a limited endogenous kidney ECFC proliferative potential contributes to impaired vascular repair and sustained rarefaction following injury. Whether cell-based therapies may have a future in treating patients with AKI is not yet clear. While preclinical data using ECFC, pro-angiogenic cells or their conditioned media indicate the potential to preserve vascular function in AKI, translating these observations to the clinic represents a significant hurdle. We propose cell-based therapies in AKI, or any therapeutic study in AKI, should not be restricted to acute hospital outcomes but incorporate the potential development of subsequent CKD following discharge of AKI survivors, which may take months or years to manifest. We envision that agents with little obvious acute protective effect in the recovery period may provide long-term benefit and that such goals should be considered in clinical study design.

From a revascularization point of view, the inability of ECFC to home to the kidney following I/R hampers efforts to facilitate vascular remodeling and is a hurdle that must be overcome. By extension, supplementing with high proliferative ECFC may result in improved vascularization, if retention and integration could be achieved. Future studies 
should investigate how improved methods of administration of cells could help overcome barriers toward homing of ECFC and facilitate repair. It is possible that a combination of bone marrow derived pro-angiogenic cells with ECFC may help to revascularize the kidney. In support of this hypothesis, co-culture of these two cell types promoted cooperative formation of capillary-like structures in Matrigel plugs, while co-adoptive transfer of both cell types in hind limb ischemia promotes greater in vivo neo-angiogenesis when compared to a single cell transfers alone ${ }^{117}$. It is of interest that Chade et al., have demonstrated that administration of endothelial progenitors described as a mix of "early" and "late" outgrowth cells directly into the renal artery of swine with renal artery stenosis improved in renal vascular structure, renal function and an attenuated renal fibrosis ${ }^{118}$.

New approaches such as the use of stromal vascular fraction (SVF), which contain both ECFC like cells and pro-angiogenic trophic cells could be used as SVF has been shown in animal models to attenuate the development of AKI and progressive CKD following I/R ${ }^{119}$. Similarly, we demonstrated that human adipose derived stromal cells could prevent the loss of renal peritubular capillaries and limit renal fibrosis up to 1 week after recovery from renal ischemia reperfusion in rats ${ }^{120}$. Therefore, a combination of different cells with cooperative activities could be envisioned to improve vascular repair or prevent capillary loss following kidney injury as a means to enable better long term renal function.

Finally, it will be important to more fully understand the biological basis for low level of ECFC proliferative potential in kidney. At the current time, these progenitor cells can only be effectively studied and identified ex vivo using clonal analysis. No unique set of markers has yet been identified for HPP ECFC, although efforts are clearly underway to identify key genes regulating ECFC activity ${ }^{88}$. If proper markers can be identified, it may enable efforts 
to study the nature of ECFC activity in the kidney, the pathways that subserve the high

proliferative potential, and even perhaps to devise strategies to influence progenitor activity

of the renal EC themselves.

\section{Acknowledgements:}

Support for studies by the authors reviewed in this paper are summarized as follows:

DPB was supported by NIH grant DK-063114 and Fortune Fry Fund and Bridge Funding

from the Indiana University Research Foundation and pilot funding from the George M

O’Brien Center P30-DK79312 (Molitoris, program director). Support for JAC was by NIH

T32 HL079995-10 (K. March, PI) and an NIH/CATS postdoctoral fellowship TL1R001107

(A.Shekar, PI). MCY was partially supported by funds from the National Institutes of Health

grant DK106846 and National Center for Advancing Translational Sciences grant TR000006

and the Riley Children's Hospital Foundation.

Conflict of Interest: The authors report no conflict of interest.

\section{References}

1. Basile, DP, Anderson, M, Sutton, TA: Pathophysiology of acute kidney injury. Comprehensive Physiology, 2: 1303-1353, 2012.

2. Basile, DP, Bonventre, JV, Mehta, R, Nangaku, M, Unwin, R, Rosner, MH, Kellum, JA, Ronco, C, Group, tAXW: Progression after AKI: Understanding Maladaptive Repair Processes to Predict and Identify Therapeutic Treatments. Journal of the American Society of Nephrology, 27: 687-697, 2016.

3. Chawla, LS, Eggers, PW, Star, RA, Kimmel, PL: Acute Kidney Injury and Chronic Kidney Disease as Interconnected Syndromes. New England Journal of Medicine, 371: 58-66, 2014.

4. Coca, SG, Singanamala, S, Parikh, CR: Chronic kidney disease after acute kidney injury: a systematic review and meta-analysis. Kidney Int, 81: 442-448, 2012.

5. Basile, DP: The endothelial cell in ischemic acute kidney injury: implications for acute and chronic function. Kidney International 72: 151-156, 2007.

6. Matejovic, M, Ince, C, Chawla, LS, Blantz, R, Molitoris, BA, Rosner, MH, Okusa, MD, Kellum, JA, Ronco, C: Renal Hemodynamics in AKI: In Search of New Treatment Targets. Journal of the American Society of Nephrology, 27: 49-58, 2016.

This article is protected by copyright. All rights reserved. 
7. Fahling, M, Seeliger, E, Patzak, A, Persson, PB: Understanding and preventing contrastinduced acute kidney injury. Nat Rev Nephrol, 13: 169-180, 2017.

8. Basile, D, Yoder, M: Renal endothelial dysfunction in acute kidney ischemia reperfusion. Cardiovascular \& Haematological Disorders-Drug Targets, 14: 3-14, 2014.

9. Evans, RG, Ince, C, Joles, JA, Smith, DW, May, CN, O'Connor, PM, Gardiner, BS: Haemodynamic influences on kidney oxygenation: The clinical implications of integrative physiology. Clinical and Experimental Pharmacology and Physiology: n/a-n/a, 2012.

10. Molitoris, BA: Therapeutic translation in acute kidney injury: the epithelial/endothelial axis. The Journal of Clinical Investigation, 124: 2355-2363, 2014.

11. Brodsky, SV, Goligorsky, MS: ENDOTHELIUM UNDER STRESS: LOCAL AND SYSTEMIC MESSAGES. Seminars in Nephrology, 32: 192-198, 2012.

12. Kwon, O, Hong, S-M, Sutton, TA, Temm, CJ: Preservation of peritubular capillary endothelial integrity and increasing pericytes may be critical to recovery from postischemic acute kidney injury. Am J Physiol Renal Physiol, 295: F351-359, 2008.

13. Molitoris, BA, Sutton, TA: Endothelial injury and dysfunction: role in the extension phase of acute renal failure. Kidney International, 66: 496-499, 2004.

14. Yasuda, K, Vasko, R, Hayek, P, Ratliff, B, Bicer, H, Mares, J, Maruyama, S, Bertuglia, S, Mascagni, P, Goligorsky, MS: Functional consequences of inhibiting exocytosis of Weibel-Palade bodies in acute renal ischemia. American Journal of Physiology Renal Physiology, 302: F713-F721, 2012.

15. Boesen, EI, Crislip, GR, Sullivan, JC: Use of ultrasound to assess renal reperfusion and P-selectin expression following unilateral renal ischemia. American Journal of Physiology - Renal Physiology, 303: F1333-F1340, 2012.

16. Zizzi, HC, Zibari, GB, Granger, DN, Singh, I, Cruz, LD, Abreo, F, McDonald, JC, Brown, MF: Quantification of P-selectin expression after renal ischemia and reperfusion. Journal of Pediatric Surgery, 32: 1010-1013, 1997.

17. Farrar, CA, Wang, Y, Sacks, SH, Zhou, W: Independent Pathways of P-Selectin and Complement-Mediated Renal Ischemia/Reperfusion Injury. The American Journal of Pathology, 164: 133-141, 2004.

18. Kelly, KJ, Williams, WW, Jr., Colvin, RB, Bonventre, JV: Antibody to intercellular adhesion molecule 1 protects the kidney against ischemic injury. Proceedings of the National Academy of Sciences of the United States of America, 91: 812-816, 1994.

19. Collett, JA, Mehrotra, P, Crone, A, Shelley, WC, Yoder, MC, Basile, DP: Endothelial colony forming cells ameliorate endothelial dysfunction via secreted factors following ischemia-reperfusion injury. American Journal of Physiology - Renal Physiology, 2017.

20. De Greef, K, Ysebaert, D, Dauwe, S, Persy, V, Vercauteren, S, Mey, D, De Broe, M: Anti B7-1 blocks mononuclear cell adherence in vasa recta after ischemia. Kidney International, 60: 1415-1427, 2001.

21. Sutton, TA, Mang, HE, Campos, SB, Sandoval, RM, Yoder, MC, Molitoris, BA: Injury of the renal microvascular endothelium alters barrier function after ischemia. American Journal of Physiology - Renal Physiology, 285: F191-198, 2003.

22. Liu, S, Soong, Y, Seshan, SV, Szeto, HH: Novel cardiolipin therapeutic protects endothelial mitochondria during renal ischemia and mitigates microvascular rarefaction, inflammation, and fibrosis. American Journal of Physiology - Renal Physiology, 306: F970-F980, 2014.

23. Sutton, TA: Alteration of microvascular permeability in acute kidney injury. Microvascular Research, 77: 4-7, 2009.

This article is protected by copyright. All rights reserved. 
24. Mandal, AK, Taylor, CA, Bell, RD, Hillman, NM, Jarnot, MD, Cunningham, JD, Phillips, LG: Erythrocyte deformation in ischemic acute tubular necrosis and amelioration by splenectomy in the dog. Lab Invest, 65: 566-576, 1991.

25. Lerolle, N, Nochy, D, Guérot, E, Bruneval, P, Fagon, J-Y, Diehl, J-L, Hill, G: Histopathology of septic shock induced acute kidney injury: apoptosis and leukocytic infiltration. Intensive Care Medicine, 36: 471-478, 2010.

26. Solez, K, Kramer, E, RH, H: PATHOLOGY OF ACUTE RENAL-FAILURELEUKOCYTE ACCUMULATION IN VASA RECTA. AMERICAN JOURNAL OF PATHOLOGY. AMER SOC INVESTIGATIVE PATHOLOGY, INC 428 EAST PRESTON ST, BALTIMORE, MD 21202-3993, 1974 pp A31-A32.

27. Le Dorze, M, Legrand, M, Payen, D, Ince, C: The role of the microcirculation in acute kidney injury. Current Opinion in Critical Care, 15: 503-508, 2009.

28. Kellum, JA, Lameire, N: Diagnosis, evaluation, and management of acute kidney injury: a KDIGO summary (Part 1). Critical Care, 17: 1-15, 2013.

29. Collett, JA, Corridon, PR, Mehrotra, P, Kolb, AL, Rhodes, GJ, Miller, CA, Molitoris, BA, Pennington, JG, Sandoval, RM, Atkinson, SJ, Campos-Bilderback, SB, Basile, DP, Bacallao, RL: Hydrodynamic Isotonic Fluid Delivery Ameliorates Moderate-toSevere Ischemia-Reperfusion Injury in Rat Kidneys. Journal of the American Society of Nephrology, 2017.

30. Basile, DP, Donohoe, DL, Roethe, K, Osborn, JL: Renal ischemic injury results in permanent damage to peritubular capillaries and influences long-term function. American Journal of Physiology, 281: F887-F899, 2001.

31. Horbelt, M, Lee, S-Y, Mang, HE, Knipe, NL, Sado, Y, Kribben, A, Sutton, TA: Acute and chronic microvascular alterations in a mouse model of ischemic acute kidney injury. Am J Physiol Renal Physiol, 293: F688-695, 2007.

32. Pechman, KR, De Miguel, C, Lund, H, Leonard, EC, Basile, DP, Mattson, DL: Recovery from renal ischemia-reperfusion injury is associated with altered renal hemodynamics, blunted pressure natriuresis, and sodium-sensitive hypertension. Am J Physiol Regul Integr Comp Physiol, 297: R1358-1363, 2009.

33. Basile, DP: Rarefaction of peritubular capillaries following ischemic acute renal failure: a potential factor predisposing progressive nephropathy. Current Opinion in Nephrology and Hypertension, 13: 1-13, 2004.

34. Eardley, KS, Kubal, C, Zehnder, D, Quinkler, M, Lepenies, J, Savage, CO, Howie, AJ, Kaur, K, Cooper, MS, Adu, D, Cockwell, P: The role of capillary density, macrophage infiltration and interstitial scarring in the pathogenesis of human chronic kidney disease. Kidney Int, 74: 495-504, 2008.

35. Chade, AR, Kelsen, S: Reversal of renal dysfunction by targeted administration of VEGF into the stenotic kidney: a novel potential therapeutic approach. American Journal of Physiology - Renal Physiology, 302: F1342-F1350, 2012.

36. Rossi, C, Artunc, F, Martirosian, P, Schlemmer, H-P, Schick, F, Boss, A: Histogram Analysis of Renal Arterial Spin Labeling Perfusion Data Reveals Differences Between Volunteers and Patients With Mild Chronic Kidney Disease. Investigative Radiology, 47: 490-496, 2012.

37. Venkatachalam, MA, Weinberg, JM, Kriz, W, Bidani, AK: Failed Tubule Recovery, AKI-CKD Transition, and Kidney Disease Progression. Journal of the American Society of Nephrology, 2015.

38. Lin, S, Chang, F, Schrimpf, C, Chen, Y, Wu, C, Wu, V, Chiang, W, Kuhnert, F, Kuo, C, Chen, Y, Wu, K, Tsai, T, duffield, J: Targetting endothelium pericyte cross talk by inhibiting VEGF receptor signaling attenuates kidney microvascular rarefaction and fibrosis. Am J Pathol, 178: 911-923, 2011.

This article is protected by copyright. All rights reserved. 
39. Grgic, I, Campanholle, G, Bijol, V, Wang, C, Sabbisetti, VS, Ichimura, T, Humphreys, $\mathrm{BD}$, Bonventre, JV: Targeted proximal tubule injury triggers interstitial fibrosis and glomerulosclerosis. Kidney Int, 82: 172-183, 2012.

40. Yang, L, Besschetnova, TY, Brooks, CR, Shah, JV, Bonventre, JV: Epithelial cell cycle arrest in G2/M mediates kidney fibrosis after injury. Nat Med, 16: 535-543, 2010.

41. Takaori, K, Nakamura, J, Yamamoto, S, Nakata, H, Sato, Y, Takase, M, Nameta, M, Yamamoto, T, Economides, AN, Kohno, K, Haga, H, Sharma, K, Yanagita, M: Severity and Frequency of Proximal Tubule Injury Determines Renal Prognosis. Journal of the American Society of Nephrology, 2015.

42. Suzuki, T, Kimura, M, Asano, M, Fujigaki, Y, Hishida, A: Role of atrophic tubules in development of interstitial fibrosis in microembolism-induced renal failure in rat. American Journal of Pathology, 158: 75-85, 2001.

43. Basile, DP, Friedrich, JL, Spahic, J, Knipe, NL, Mang, HE, Leonard, EC, Ashtiyani, SC, Bacallao, RL, Molitoris, BA, Sutton, TA: Impaired endothelial proliferation and mesenchymal transition contribute to vascular rarefaction following acute kidney injury. American Journal of Physiology - Renal Physiology, 300: F721-733, 2011.

44. Patschan, D, Schwarze, K, Henze, E, Patschan, S, Müller, GA: The endothelial-tomesenchymal transition and endothelial cilia in EPC-mediated postischemic kidney protection. American Journal of Physiology - Renal Physiology, 310: F679-F687, 2016.

45. Lin, S-L, Chang, F-C, Schrimpf, C, Chen, Y-T, Wu, C-F, Wu, V-C, Chiang, W-C, Kuhnert, F, Kuo, CJ, Chen, Y-M, Wu, K-D, Tsai, T-J, Duffield, JS: Targeting Endothelium-Pericyte Cross Talk by Inhibiting VEGF Receptor Signaling Attenuates Kidney Microvascular Rarefaction and Fibrosis. The American journal of pathology, 178: 911-923, 2011.

46. Schrimpf, C, Xin, C, Campanholle, G, Gill, SE, Stallcup, W, Lin, SL, Davis, GE, Gharib, SA, Humphreys, BD, Duffield, JS: Pericyte TIMP3 and ADAMTS1 modulate vascular stability after kidney injury. Journal of the American Society of Nephrology : JASN, 23: 868-883, 2012.

47. Basile, DP, Fredrich, K, Chelladurai, B, Leonard, EC, Parrish, AR: Renal ischemia reperfusion inhibits VEGF expression and induces ADAMTS-1, a novel VEGF inhibitor. Am J Physiol Renal Physiol, 294, 2008

48. O'Riordan, E, Mendelev, N, Patschan, S, Patschan, D, Eskander, J, Cohen-Gould, L, Chander, P, Goligorsky, MS: Chronic NOS inhibition actuates endothelialmesenchymal transformation. Am J Physiol Heart Circ Physiol, 292: H285-294, 2007.

49. Goligorsky, MS: Microvascular rarefaction: The decline and fall of blood vessels. Organogenesis, 6: 1-10, 2010.

50. Basile, DP, Zeng, P, Friedrich, JL, Leonard, E, Yoder, MC: Low proliferative potential and impaired angiogenesis of cultured rat kidney endothelial cells. Microcirculation, 19: 598-609, 2012

51. Ehling, J, Bábíčková, J, Gremse, F, Klinkhammer, BM, Baetke, S, Knuechel, R, Kiessling, F, Floege, J, Lammers, T, Boor, P: Quantitative Micro-Computed Tomography Imaging of Vascular Dysfunction in Progressive Kidney Diseases. Journal of the American Society of Nephrology : JASN, 27: 520-532, 2016.

52. Medina, RJ, Barber, CL, Sabatier, F, Dignat-George, F, Melero-Martin, JM, Khosrotehrani, K, Ohneda, O, Randi, AM, Chan, JKY, Yamaguchi, T, Van Hinsbergh, VWM, Yoder, MC, Stitt, AW: Endothelial Progenitors: A Consensus Statement on Nomenclature. STEM CELLS Translational Medicine: n/a-n/a, 2017.

This article is protected by copyright. All rights reserved. 
53. Basile, DP, Yoder, MC: Circulating and Tissue Resident Endothelial Progenitor Cells. Journal of Cellular Physiology, 229: 10-16, 2014.

54. Wara, AK, Croce, K, Foo, S, Sun, X, Icli, B, Tesmenitsky, Y, Esen, F, Rosenzweig, A, Feinberg, MW: Bone marrow-derived CMPs and GMPs represent highly functional proangiogenic cells: implications for ischemic cardiovascular disease. Blood, 118: 6461-6464, 2011.

55. Yoder, MC, Mead, LE, Prater, D, Krier, TR, Mroueh, KN, Li, F, Krasich, R, Temm, CJ, Prchal, JT, Ingram, DA: Redefining endothelial progenitor cells via clonal analysis and hematopoietic stem/progenitor cell principals. Blood, 109: 1801-1809, 2007.

56. Rose, JA, Erzurum, S, Asosingh, K: Biology and flow cytometry of proangiogenic hematopoietic progenitors cells. Cytometry Part A, 87: 5-19, 2015.

57. Estes, ML, Mund, JA, Mead, LE, Prater, DN, Cai, S, Wang, H, Pollok, KE, Murphy, MP, An, CST, Srour, EF, Ingram, DA, Case, J: Application of polychromatic flow cytometry to identify novel subsets of circulating cells with angiogenic potential. Cytometry Part A, 77A: 831-839, 2010.

58. Purhonen, S, Palm, J, Rossi, D, Kaskenpää, N, Rajantie, I, Ylä-Herttuala, S, Alitalo, K, Weissman, IL, Salven, P: Bone marrow-derived circulating endothelial precursors do not contribute to vascular endothelium and are not needed for tumor growth. Proceedings of the National Academy of Sciences, 105: 6620-6625, 2008.

59. Göthert, JR, Gustin, SE, van Eekelen, JAM, Schmidt, U, Hall, MA, Jane, SM, Green, AR, Göttgens, B, Izon, DJ, Begley, CG: Genetically tagging endothelial cells in vivo: bone marrow-derived cells do not contribute to tumor endothelium. Blood, 104: 1769-1777, 2004.

60. Rajantie, I, Ilmonen, M, Alminaite, A, Ozerdem, U, Alitalo, K, Salven, P: Adult bone marrow-derived cells recruited during angiogenesis comprise precursors for periendothelial vascular mural cells. Blood, 104: 2084-2086, 2004.

61. Perry, TE, Song, M, Despres, DJ, Kim, SM, San, H, Yu, Z-X, Raghavachari, N, Schnermann, J, Cannon, IIIRO, Orlic, D: Bone marrow-derived cells do not repair endothelium in a mouse model of chronic endothelial cell dysfunction.

Cardiovascular Research, 84: 317-325, 2009.

62. Ohtani, K, Vlachojannis, GJ, Koyanagi, M, Boeckel, J-N, Urbich, C, Farcas, R, Bonig, H, Marquez, VE, Zeiher, AM, Dimmeler, S: Epigenetic Regulation of Endothelial Lineage Committed Genes in Pro-Angiogenic Hematopoietic and Endothelial Progenitor Cells: Novelty and Significance. Circulation Research, 109: 1219-1229, 2011.

63. De Palma, M, Naldini, L: Angiopoietin-2 TIEs Up Macrophages in Tumor Angiogenesis. Clinical Cancer Research, 17: 5226-5232, 2011.

64. Willenborg, S, Lucas, T, van Loo, G, Knipper, JA, Krieg, T, Haase, I, Brachvogel, B, Hammerschmidt, M, Nagy, A, Ferrara, N, Pasparakis, M, Eming, SA: CCR2 recruits an inflammatory macrophage subpopulation critical for angiogenesis in tissue repair. Blood, 120: 613-625, 2012.

65. Laurent, J, Touvrey, C, Botta, F, Kuonen, F, Ruegg, C: Emerging paradigms and questions on pro-angiogenic bone marrow derived myelomonocytic cells. Int J Dev Biol, 55: 527-534, 2011.

66. Asahara, T, Murohara, T, Sullivan, A, Silver, M, van der Zee, R, Li, T, Witzenbichler, B, Schatteman, G, Isner, JM: Isolation of Putative Progenitor Endothelial Cells for Angiogenesis. Science, 275: 964-966, 1997.

67. Asahara, T, Masuda, H, Takahashi, T, Kalka, C, Pastore, C, Silver, M, Kearne, M, Magner, M, Isner, JM: Bone Marrow Origin of Endothelial Progenitor Cells

This article is protected by copyright. All rights reserved. 
Responsible for Postnatal Vasculogenesis in Physiological and Pathological Neovascularization. Circulation Research, 85: 221-228, 1999.

68. Peichev, M, Naiyer, AJ, Pereira, D, Zhu, Z, Lane, WJ, Williams, M, Oz, MC, Hicklin, DJ, Witte, L, Moore, MAS, Rafii, S: Expression of VEGFR-2 and AC133 by circulating human CD34+ cells identifies a population of functional endothelial precursors. Blood, 95: 952-958, 2000.

69. Hill, JM, Zalos , G, Halcox , JPJ, Schenke, WH, Waclawiw , MA, Quyyumi, AA, Finkel , T: Circulating Endothelial Progenitor Cells, Vascular Function, and Cardiovascular Risk. New England Journal of Medicine, 348: 593-600, 2003.

70. Fadini, GP, Agostini, C, Avogaro, A: Autologous stem cell therapy for peripheral arterial disease: Meta-analysis and systematic review of the literature. Atherosclerosis, 209: 10-17, 2010.

71. Yoder, MC: Endothelial progenitor cell: a blood cell by many other names may serve similar functions. Journal of Molecular Medicine, 91: 285-295, 2013.

72. Asahara, T, Kawamoto, A, Masuda, H: Concise Review: Circulating Endothelial Progenitor Cells for Vascular Medicine. STEM CELLS, 29: 1650-1655, 2011.

73. Murohara, T, Ikeda, H, Duan, J, Shintani, S, Sasaki, K-i, Eguchi, H, Onitsuka, I, Matsui, K, Imaizumi, T: Transplanted cord blood-derived endothelial precursor cells augment postnatal neovascularization. The Journal of Clinical Investigation, 105: 1527-1536, 2000.

74. Kim, H, Cho, H-J, Kim, S-W, Liu, B, Choi, YJ, Lee, J, Sohn, Y-D, Lee, M-Y, Houge, MA, Yoon, Y-s: CD31(+) cells represent highly angiogenic and vasculogenic cells in bone marrow: novel role of non-endothelial CD31 $(+)$ cells in neovascularization and their therapeutic effects on ischemic vascular disease. Circulation research, 107: 602$614,2010$.

75. Case, J, Mead, LE, Bessler, WK, Prater, D, White, HA, Saadatzadeh, MR, Bhavsar, JR, Yoder, MC, Haneline, LS, Ingram, DA: Human CD34+AC133+VEGFR-2+ cells are not endothelial progenitor cells but distinct, primitive hematopoietic progenitors. Experimental hematology, 35: 1109-1118, 2007.

76. Timmermans, F, Plum, J, Yöder, MC, Ingram, DA, Vandekerckhove, B, Case, J: Endothelial progenitor cells: identity defined? Journal of Cellular and Molecular Medicine, 13: 87-102, 2009.

77. Hayek, SS, MacNamara, J, Tahhan, AS, Awad, M, Yadalam, A, Ko, Y-A, Healy, S, Hesaroieh, I, Ahmed, H, Gray, B, Sher, SS, Ghasemzadeh, N, Patel, R, Kim, J, Waller, EK, Quyyumi, AA: Circulating Progenitor Cells Identify Peripheral Arterial Disease in Patients With Coronary Artery Disease: Novelty and Significance. Circulation Research, 119: 564-571, 2016.

78. Hayek, SS, Klyachkin, Y, Asfour, A, Ghasemzadeh, N, Awad, M, Hesaroieh, I, Ahmed, H, Gray, B, Kim, J, Waller, EK, Quyyumi, AA, Abdel-Latif, AK: Bioactive Lipids and Circulating Progenitor Cells in Patients with Cardiovascular Disease. STEM CELLS Translational Medicine, 6: 731-735, 2017.

79. Fadini, GP, Losordo, D, Dimmeler, S: Critical re-evaluation of endothelial progenitor cell phenotypes for therapeutic and diagnostic use. Circulation Research, 110: 624-637, 2012.

80. Rehman, J, Li, J, Orschell, CM, March, KL: Peripheral Blood Endothelial Progenitor Cells Are Derived From Monocyte/Macrophages and Secrete Angiogenic Growth Factors. Circulation, 107: 1164-1169, 2003.

81. Joshi, S, Singh, AR, Zulcic, M, Durden, DL: A Macrophage-Dominant PI3K Isoform Controls Hypoxia-Induced HIF1 $\alpha$ and HIF2 $\alpha$ Stability and Tumor Growth, Angiogenesis, and Metastasis. Molecular Cancer Research, 12: 1520-1531, 2014.

This article is protected by copyright. All rights reserved. 
82. He, L, Marneros, AG: Doxycycline inhibits polarization of macrophages to the proangiogenic M2-type and subsequent neovascularization. Journal of Biological Chemistry, 2014.

83. Newman, AC, Hughes, CCW: Macrophages and angiogenesis: a role for Wnt signaling. Vascular Cell, 4: 13, 2012.

84. Lin, Y, Weisdorf, DJ, Solovey, A, Hebbel, RP: Origins of circulating endothelial cells and endothelial outgrowth from blood. Journal of Clinical Investigation, 105: 71-77, 2000.

85. Ingram, DA, Mead, LE, Tanaka, H, Meade, V, Fenoglio, A, Mortell, K, Pollok, K, Ferkowicz, MJ, Gilley, D, Yoder, MC: Identification of a novel hierarchy of endothelial progenitor cells using human peripheral and umbilical cord blood. Blood, 104: 2752-2760, 2004.

86. Woywodt, A, Blann, AD, Kirsch, T, Erdbruegger, U, Banzet, N, Haubitz, M, DignatGeorge, F: Isolation and enumeration of circulating endothelial cells by immunomagnetic isolation: proposal of a definition and a consensus protocol. Journal of Thrombosis and Haemostasis, 4: 671-677, 2006.

87. Yoder, MC: Is Endothelium the Origin of Endothelial Progenitor Cells? Arteriosclerosis, Thrombosis, and Vascular Biology, 30: 1094-1103, 2010.

88. Prasain, N, Lee, MR, Vemula, S, Meador, JL, Yoshimoto, M, Ferkowicz, MJ, Fett, A, Gupta, M, Rapp, BM, Saadatzadeh, MR, Ginsberg, M, Elemento, O, Lee, Y, VoytikHarbin, SL, Chung, HM, Hong, KS, Reid, E, O'Neill, CL, Medina, RJ, Stitt, AW, Murphy, MP, Rafii, S, Broxmeyer, HE, Yoder, MC: Differentiation of human pluripotent stem cells to cells similar to cord-blood endothelial colony-forming cells. Nat Biotech, 32: 1151-1157, 2014.

89. Newey, SE, Tsaknakis, G, Khoo, CP, Athanassopoulos, T, Camicia, R, Zhang, Y, Grabowska, R, Harris, AL, Roubelakis, MG, Watt, SM: The Hematopoietic Chemokine CXCL12 Promotes Integration of Human Endothelial Colony Forming Cell-Derived Cells into Immature Vessel Networks. Stem Cells and Development, 23: 2730-2743, 2014.

90. Alphonse, RS, Vadivel, A, Fung, M, Shelley, WC, Critser, PJ, Ionescu, L, O'Reilly, M, Ohls, RK, McConaghy, S, Eaton, F, Zhong, S, Yoder, M, Thébaud, B: Existence, Functional Impairment, and Lung Repair Potential of Endothelial Colony-Forming Cells in Oxygen-Induced Arrested Alveolar GrowthCLINICAL PERSPECTIVE. Circulation, 129: 2144-2157, 2014.

91. Viñas, JL, Burger, D, Zimpelmann, J, Haneef, R, Knoll, W, Campbell, P, Gutsol, A, Carter, A, Allan, DS, Burns, KD: Transfer of microRNA-486-5p from human endothelial colony forming cell-derived exosomes reduces ischemic kidney injury. Kidney International, 90: 1238-1250, 2016.

92. Khakoo, AY, Finkel, T: Endothelial Progenitor Cells. Annual Review of Medicine, 56: 79-101, 2004.

93. Kiernan, TJ, Boilson, BA, Witt, TA, Dietz, AB, Lerman, A, Simari, RD: Vasoprotective effects of human CD34+ cells: towards clinical applications. Journal of Translational Medicine, 7: 66-66, 2009.

94. Ahrens, I, Domeij, H, Topcic, D, Haviv, I, Merivirta, R-M, Agrotis, A, Leitner, E, Jowett, JB, Bode, C, Lappas, M, Peter, K: Successful In Vitro Expansion and Differentiation of Cord Blood Derived CD34+ Cells into Early Endothelial Progenitor Cells Reveals Highly Differential Gene Expression. PLoS ONE, 6: e23210, 2011.

95. Hohenstein, B, Kuo, M-C, Addabbo, F, Yasuda, K, Ratliff, B, Schwarzenberger, C, Eckardt, K-U, Hugo, CPM, Goligorsky, MS: Enhanced progenitor cell recruitment

This article is protected by copyright. All rights reserved. 
and endothelial repair after selective endothelial injury of the mouse kidney. American Journal of Physiology - Renal Physiology, 298: F1504-F1514, 2010.

96. Togel, F, Isaac, J, Hu, Z, Weiss, K, Westenfelder, C: Renal SDF-1 signals mobilization and homing of CXCR4-positive cells to the kidney after ischemic injury. Kidney Int, 67: 1772-1784, 2005.

97. Reinders, MEJ, Rabelink, TJ, Briscoe, DM: Angiogenesis and Endothelial Cell Repair in Renal Disease and Allograft Rejection. Journal of the American Society of Nephrology, 17: 932-942, 2006.

98. Chade, AR, Zhu, X-Y, Krier, JD, Jordan, KL, Textor, SC, Grande, JP, Lerman, A, Lerman, LO: Endothelial Progenitor Cells Homing and Renal Repair in Experimental Renovascular Disease. STEM CELLS, 28: 1039-1047, 2010.

99. Patschan, D, Patschan, S, Gobe, GG, Chintala, S, Goligorsky, MS: Uric Acid Heralds Ischemic Tissue Injury to Mobilize Endothelial Progenitor Cells. Journal of the American Society of Nephrology, 18: 1516-1524, 2007.

100. Patschan, D, Krupincza, K, Patschan, S, Zhang, Z, Hamby, C, Goligorsky, MS: Dynamics of mobilzation and homing of endothelial progenitor cells after acute renal ischemia: modulation by ischemic preconditioning. . Am J Physiol, 291: F176-F185, 2006.

101. Patschan, D, Patschan, S, Wessels, JT, Becker, JU, David, S, Henze, E, Goligorsky, MS, Müller, GA: Epac-1 activator 8-O-cAMP augments renoprotective effects of allogeneic murine EPCs in acute ischemic kidney injury. American Journal of Physiology - Renal Physiology, 298: F78-F85, 2010.

102. Patschan, D, Patschan, S, Muller, GA: Endothelial Progenitor Cells in Acute Ischemic Kidney Injury: Strategies for Increasing the Cells' Renoprotective Competence. International Journal of Nephrology, 2011, 2011.

103. Burger, D, Gutsol, A, Carter, A, Allan, DS, Touyz, RM, Burns, KD: Human cord blood CD133+ cells exacerbate ischemic acute kidney injury in mice. Nephrology Dialysis Transplantation, 2012.

104. Li, B, Cohen, A, Hudson, TE, Motlagh, D, Amrani, DL, Duffield, JS: Mobilized Human Hematopoietic Stem/Progenitor Cells Promote Kidney Repair After Ischemia/Reperfusion Injury. Circulation, 121: 2211-2220, 2010.

105. Kwon, O, Miller, S, Li, N, Khan, A, Kadry, Z, Uemura, T: Bone Marrow-derived Endothelial Progenitor Cells and Endothelial Cells May Contribute to Endothelial Repair in the Kidney Immediately After Ischemia-Reperfusion. Journal of Histochemistry and Cytochemistry, 58: 687-694, 2010.

106. Goligorsky, MS, Kuo, M-C, Patschan, D, Verhaar, MC: Review article: Endothelial progenitor cells in renal disease. Nephrology, 14: 291-297, 2009.

107. Hirschi, KK, Ingram, DA, Yoder, MC: Assessing Identity, Phenotype, and Fate of Endothelial Progenitor Cells. Arteriosclerosis, Thrombosis, and Vascular Biology, 28: 1584-1595, 2008.

108. Ingram, DA, Mead, LE, Moore, DB, Woodard, W, Fenoglio, A, Yoder, MC: Vessel wall-derived endothelial cells rapidly proliferate because they contain a complete hierarchy of endothelial progenitor cells. Blood, 105: 2783-2786, 2005.

109. Schwarz, TM, Leicht, SF, Radic, T, Rodriguez-Arabaolaza, I, Hermann, PC, Berger, F, Saif, J, Böcker, W, Ellwart, JW, Aicher, A, Heeschen, C: Vascular Incorporation of Endothelial Colony-Forming Cells Is Essential for Functional Recovery of Murine Ischemic Tissue Following Cell Therapy. Arteriosclerosis, Thrombosis, and Vascular Biology, 32: e13-e21, 2012.

110. Yamamoto, T, Tada, T, Brodsky, SV, Tanaka, H, Noiri, E, Kajiya, F, Goligorsky, MS: Intravital videomicroscopy of peritubular capillaries in renal ischemia. American

This article is protected by copyright. All rights reserved. 
Journal of Physiology - Renal Fluid \& Electrolyte Physiology, 282: F1150-1155, 2002.

111. Brodsky, SV, Yamamoto, T, Tada, T, Kim, B, Chen, J, Kajiya, F, Goligorsky, MS: Endothelial dysfunction in ischemic acute renal failure: rescue by transplanted endothelial cells. American Journal of Physiology - Renal Fluid \& Electrolyte Physiology, 282: F1140-1149, 2002.

112. Burger, D, Viñas, JL, Akbari, S, Dehak, H, Knoll, W, Gutsol, A, Carter, A, Touyz, RM, Allan, DS, Burns, KD: Human Endothelial Colony-Forming Cells Protect against Acute Kidney Injury. The American Journal of Pathology, 185: 2309-2323, 2015.

113. Pang, P, Abbott, M, Chang, SL, Abdi, M, Chauhan, N, Mistri, M, Ghofrani, J, Fucci, QA, Walker, C, Leonardi, C, Grady, S, Halim, A, Hoffman, R, Lu, T, Cao, H, Tullius, SG, Malek, S, Kumar, S, Steele, G, Kibel, A, Freedman, BS, Waikar, SS, Siedlecki, AM: Human vascular progenitor cells derived from renal arteries are endothelial-like and assist in the repair of injured renal capillary networks. Kidney International, 91: 129-143, 2017.

114. Patschan, D, Schwarze, K, Tampe, B, Zeisberg, M, Patschan, S, Müller, GA: Endothelial Colony Forming Cells (ECFCs) in murine AKI - implications for future cell-based therapies. BMC Nephrology, 18: 53, 2017.

115. Cantaluppi, V, Gatti, S, Medica, D, Figliolini, F, Bruno, S, Deregibus, MC, Sordi, A, Biancone, L, Tetta, C, Camussi, G: Microvesicles derived from endothelial progenitor cells protect the kidney from ischemia-reperfusion injury by microRNA-dependent reprogramming of resident renal cells. Kidney Int, 82: 412-427, 2012.

116. Camussi, G, Deregibus, MC, Bruno, S, Cantaluppi, V, Biancone, L:

Exosomes/microvesicles as a mechanism of cell-to-cell communication. Kidney International, 78: 838-848.

117. Yoon, C-H, Hur, J, Park, K-W, Kim, J-H, Lee, C-S, Oh, I-Y, Kim, T-Y, Cho, H-J, Kang, H-J, Chae, I-H, Yang, H-K, Oh, B-H, Park, Y-B, Kim, H-S: Synergistic Neovascularization by Mixed Transplantation of Early Endothelial Progenitor Cells and Late Outgrowth Endothelial Cells. Circulation, 112: 1618-1627, 2005.

118. Chade, AR, Zhu, X, Lavi, R, Krier, JD, Pislaru, S, Simari, RD, Napoli, C, Lerman, A, Lerman, LO: Endothelial Progenitor Cells Restore Renal Function in Chronic Experimental Renovascular Disease. Circulation, 119: 547-557, 2009.

119. Zhou, L, Xu, L, Shen, J, Song, Q, Wu, R, Ge, Y, Xin, H, Zhu, J, Wu, J, Jia, R: Preischemic Administration of Nonexpanded Adipose Stromal Vascular Fraction Attenuates Acute Renal Ischemia/Reperfusion Injury and Fibrosis. Stem Cells Translational Medicine, 2016.

120. Collett, J, Mehrotra, P, Crone, A, Merfeld-Clauss, S, March, KL, Traktuev, D, Basile, D: Human adipose stromal cells ameliorate ischemia-reperfusion renal injury by reducing local inflammation and attenuating capillary rarefaction. Journal of Cellular and Molecular Medicine, In press, 2017 In press

121. Patschan, D, Hildebrandt, A, Rinneburger, J, Wessels, JT, Patschan, S, Becker, JU, Henze, E, Kruger, A, Muller, GA: The hormone melatonin stimulates renoprotective effects of "early outgrowth" endothelial progenitor cells in acute ischemic kidney injury. Am J Physiol Renal Physiol, 302: F1305-1312, 2012.

122. Patschan, D, Rinneburger, J, Idrizi, N, Backhaus, R, Schwarze, K, Henze, E, Patschan, S, Müller, GA: Angiopoietin-1 treated early endothelial outgrowth cells (eEOCs) are activated in vitro and reduce renal damage in murine acute ischemic kidney injury (iAKI). BMC Nephrology, 14: 227-227, 2013.

123. Patschan, D, Schwarze, K, Lange, A, Meise, N, Henze, E, Becker, JU, Patschan, S, Muller, GA: Bone morphogenetic protein-5 and early endothelial outgrowth cells

This article is protected by copyright. All rights reserved. 
(eEOCs) in acute ischemic kidney injury (AKI) and 5/6-chronic kidney disease. Am J Physiol Renal Physiol, 305: F314-322, 2013.

124. Patschan, D, Schwarze, K, Henze, E, Patschan, S, Muller, GA: Endothelial autophagy and Endothelial-to-Mesenchymal Transition (EndoMT) in eEPC treatment of ischemic AKI. Journal of nephrology, 2015.

125. Liang, CJ, Shen, WC, Chang, FB, Wu, VC, Wang, SH, Young, GH, Tsai, JS, Tseng, YC, Peng, YS, Chen, YL: Endothelial Progenitor Cells Derived From Wharton's Jelly of Human Umbilical Cord Attenuate Ischemic Acute Kidney Injury by Increasing Vascularization and Decreasing Apoptosis, Inflammation, and Fibrosis. Cell Transplant, 24: 1363-1377, 2015.

126. Zullo, JA, Nadel, EP, Rabadi, MM, Baskind, MJ, Rajdev, MA, Demaree, CM, Vasko, R, Chugh, SS, Lamba, R, Goligorsky, MS, Ratliff, BB: The Secretome of HydrogelCoembedded Endothelial Progenitor Cells and Mesenchymal Stem Cells Instructs Macrophage Polarization in Endotoxemia. Stem Cells Transl Med, 4: 852-861, 2015.

Table 1.

\begin{tabular}{|c|c|c|c|}
\hline $\begin{array}{l}\text { Author, } \\
\text { reference, } \\
\text { year }\end{array}$ & Cell Type & Biological Source & Model/Biological Effect \\
\hline $\begin{array}{l}\text { Patschan et } \\
\text { al. }{ }^{100} 2006\end{array}$ & $\begin{array}{l}\text { Pro- } \\
\text { angiogenic }\end{array}$ & $\begin{array}{l}\text { Murine spleen } \\
\text { and kidney }\end{array}$ & $\begin{array}{l}\text { Unilateral I/R in FVB/NJ and Tie-2-GFP } \\
\text { mice } \\
\text { Reduced plasma creatinine by } \sim 50 \% \text { post } \\
\text { I/R } \\
\text { No evidence of homing }\end{array}$ \\
\hline $\begin{array}{l}\text { Patschan et } \\
\text { al. }{ }^{101} 2010\end{array}$ & $\begin{array}{l}\text { Pro- } \\
\text { angiogenic }\end{array}$ & $\begin{array}{l}\text { Murine peripheral } \\
\text { blood, spleen } \\
\text { and bone marrow }\end{array}$ & $\begin{array}{l}\text { Unilateral I/R in male C57BL/6N mice } \\
\text { Reduced plasma creatinine by } \sim 40-75 \% \\
\text { post-l/R } \\
\text { Reduced plasma creatinine by } \sim 90 \% \\
\text { post-l/R with Epac- } 1 \text { Ac pretreatment } \\
\text { Evidence of minimal homing }\end{array}$ \\
\hline $\begin{array}{l}\text { Patschan et } \\
\text { al. }{ }^{121} 2012 \\
\text { Patschan et } \\
\text { al. }{ }^{122} 2013 \\
\text { Patschan et } \\
\text { al. }{ }^{123} 2013\end{array}$ & & $\begin{array}{l}\text { Murine peripheral } \\
\text { blood and spleen }\end{array}$ & $\begin{array}{l}\text { Similar models as above; pretreatment of } \\
\text { cells with melatonin, Angiopoietin- } 1 \text { and } \\
\text { BMP- } 5 \text { enhances protective response, } \\
\text { with minimal homing }\end{array}$ \\
\hline $\begin{array}{l}\text { Patschan et } \\
\text { al. }{ }^{124} 2015 \\
\text { Patschan et } \\
\text { al. }{ }^{44} 2016\end{array}$ & $\begin{array}{l}\text { Pro- } \\
\text { angiogenic }\end{array}$ & $\begin{array}{l}\text { Murine peripheral } \\
\text { blood and spleen }\end{array}$ & $\begin{array}{l}\text { Bilateral I/R in male C57BL/6N mice, } \\
\text { reduced plasma creatinine, increased } \\
\text { endothelial autophagy and decreased } \\
\text { EndoMT and attenuated capillary } \\
\text { rarefaction }\end{array}$ \\
\hline $\begin{array}{l}\text { Burger et al. } \\
1122015\end{array}$ & $\begin{array}{l}\text { ECFC \& } \\
\text { ECFC } \\
\text { exosomes }\end{array}$ & $\begin{array}{l}\text { Human } \\
\text { umbilical cord }\end{array}$ & $\begin{array}{l}\text { Bilateral I/R in male NOD-SCID mice } \\
\text { Reduced plasma creatinine by } \sim 40 \% \\
\text { post-I/R } \\
\text { Improved tubular morphology } \\
\text { No evidence of homing }\end{array}$ \\
\hline $\begin{array}{l}\text { Collett et al. } \\
{ }^{19} 2017\end{array}$ & ECFC & $\begin{array}{l}\text { Rat PMVEC and } \\
\text { human ECFC- } \\
\text { conditioned }\end{array}$ & $\begin{array}{l}\text { Bilateral I/R in male Sprague Dawley rats } \\
\text { Reduced plasma creatinine by } \sim 50 \% \\
\text { post-l/R }\end{array}$ \\
\hline
\end{tabular}

This article is protected by copyright. All rights reserved. 


\begin{tabular}{|c|c|c|c|}
\hline & & media & $\begin{array}{l}\text { Improved tubular morphology } \\
\text { Prevented loss of medullary blood flow } \\
\text { No evidence of homing }\end{array}$ \\
\hline $\begin{array}{l}\text { Viñas et al. }{ }^{91} \\
2016\end{array}$ & ECFC & $\begin{array}{l}\text { Human umbilical } \\
\text { cord blood ECFC } \\
\text { derived } \\
\text { exosomes }\end{array}$ & $\begin{array}{l}\text { Bilateral I/R in male FVB mice } \\
\text { Reduced plasma creatinine by } \sim 90 \% \\
\text { post-I/R } \\
\text { Improved tubular morphology }\end{array}$ \\
\hline $\begin{array}{l}\text { Brodsky et } \\
\text { al. }{ }^{111} 2001\end{array}$ & EC & $\begin{array}{l}\text { Human umbilical } \\
\text { cord }\end{array}$ & $\begin{array}{l}\text { Unilateral I/R in male Athymic rats } \\
\text { Reduced plasma creatinine by } \sim 50 \% \\
\text { post-I/R } \\
\text { Maintained microvascular perfusion } \\
\text { Evidence of minimal homing }\end{array}$ \\
\hline $\begin{array}{l}\text { Cantaluppi et } \\
\text { al. }{ }^{115} 2012\end{array}$ & $\begin{array}{l}\text { ECFC derived } \\
\text { microvesicles }\end{array}$ & $\begin{array}{l}\text { Human } \\
\text { peripheral blood }\end{array}$ & $\begin{array}{l}\text { Unilateral I/R in male Wistar rats } \\
\text { Reduced plasma creatinine by } \sim 80 \% \\
\text { post-l/R } \\
\text { Improved tubular morphology } \\
\text { Prevented capillary rarefaction }\end{array}$ \\
\hline $\begin{array}{l}\text { Liang et al. } \\
{ }^{125} 2015\end{array}$ & EC & $\begin{array}{l}\text { Human Umbilical } \\
\text { cords (Wharton's } \\
\text { Jelly) }\end{array}$ & $\begin{array}{l}\text { Unilateral I/R in male C57BL/ } 6 \text { mice } \\
\text { Reduced plasma creatinine by } ~ 70 \% \\
\text { post-l/R } \\
\text { Improved tubular morphology } \\
\text { Potential prevention of capillary } \\
\text { rarefaction } \\
\text { Evidence of minimal homing }\end{array}$ \\
\hline $\begin{array}{l}\text { Pang et al. }{ }^{133} \\
2017\end{array}$ & EC or ECFC & $\begin{array}{l}\text { Human renal } \\
\text { artery }\end{array}$ & $\begin{array}{l}\text { Bilateral I/R and nephron mass reduction } \\
\text { in NOD-SCID mice. Reduced plasma } \\
\text { creatinine by } \sim 50 \% \text { post-I/R } \\
\text { Prevented capillary rarefaction } \\
\text { Minimal homing near peritubular } \\
\text { capillaries up to } 10 \text { days }\end{array}$ \\
\hline $\begin{array}{l}\text { Patschan et } \\
\text { al. }^{114} 2017\end{array}$ & Indeterminate & $\begin{array}{l}\text { Murine peripheral } \\
\text { blood and spleen }\end{array}$ & $\begin{array}{l}\text { Bilateral I/R in male C57BL/6 mice } \\
\text { Reduced plasma creatinine by } \sim 10 \% \text { at } 1 \\
\text { week, did not prevent capillary rarefaction }\end{array}$ \\
\hline $\begin{array}{l}\text { Zullo et al. } \\
2015\end{array}$ & Indeterminate & $\begin{array}{l}\text { Murine } \\
\text { embryonic EPC } \\
\text { line cultured with } \\
\text { MSCs }\end{array}$ & $\begin{array}{l}\text { Improved renal function, medullary RBF } \\
\text { and increased M1 to M2 macrophage } \\
\text { polarization in LPS induced endoxemia in } \\
\text { C57BL6 mice. }\end{array}$ \\
\hline
\end{tabular}

ECFC-endothelial colony forming cells; EC-endothelial cells

This article is protected by copyright. All rights reserved. 


\section{Figure Legends}

Figure 1. Alterations in endothelial function contribute to the extension phase of acute kidney injury. On the left, a peritubular capillary is shown in close apposition to tubular epithelium in a normal kidney. B) In response to injury, endothelial swelling narrows capillary space. Increased adhesion molecule expression facilitates leukocyte attachment, contributing to erythrocyte rouleaux formation and disrupting normal blood flow. Reduction in flow contributes to reduced shear stress and inhibition of NO formation, a potential trigger for endothelial mesenchymal transition (EndoMT). Addition potential contributors toward EndoMT include a reduction in trophic support from damaged tubules or injury activated perictyes. Disruption of blood flow exacerbates tissue hypoxia and further compromises epithelial injury and a reduction in renal

Figure 2. Failed vascular recovery leads to peritubular capillary rarefaction following AKI. Concurrent with resolution of GFR and tubular repair recovery of the capillary endothelium is inefficient due to a combination of EndoMT and low endothelial proliferation. Infiltration of pro-angiogenic hematopoietic cells provide pro-angiogenic stimulation but renal endothelium is unresponsive due to the lack of HPP-ECFC activity intrinsic in kidney. Expansion of fibroblasts or myofibroblasts, which derive from either pericyte activation or EndoMT, may occlude blood vessels leading to a rarefied capillary bed.

Figure 3. Human "endothelial progenitor cells" (EPC) have been identified using monoclonal antibodies or specific ligands to detect numerous cell surface antigens. Three key antigens CD34, AC133, and KDR are the most frequently utilized as markers for human EPC. No unique antigen has been reported that can discriminate the human EPC from other cell lineages (many of the above antigens are present on blood cells).

Figure 4. Proangiogenic hematopoietic cells (PHC) do not become endothelial cells but do stimulate resident endothelial colony forming cells (ECFC) to repair the intima. Moving from the left to the right on the image, one can visualize that any denudation injury that causes loss or turnover of the resident endothelial cells results in an area of exposed subendothelial basement membrane. Circulating platelets would be readily recruited to the exposed basement membrane and would release chemokines and growth factors to recruit circulating PHC, ranging from bone marrow progenitor cells to mature circulating monocytes and neutrophils, to assist in adhering to the basement membrane. The recruited PHC secrete a host of growth factors, chemokines, and proteolytic enzymes to stimulate the proliferation and migration of resident ECFC into the site of the injury to reconstitute the endothelial barrier and promote normal homeostatic functions through the injured vessel segment. The PHC merely migrate into the tissue where they can differentiate into mature tissue resident cells, re-enter the circulation, or undergo senescence and are cleared by macrophages in the tissues.

Figure 5. Both HPP-ECFC and pro-angiogenic hematopoietic cells can mitigate acute kidney injury. Both cell types have been shown to improve renal function and renal perfusion when administered prior to the establishment of renal injury. Possible mechanisms include a direct inhibition of adhesion molecule expression proposed to maintain perfusion in the early injury phase (See Figure 1). Maintenance of vascular structure likely is based on prevention of endothelial loss for which EndoMT represents a primary mechanism. 
Protection is likely mediated by released factors such as pro-angiogenic factors or exosomal transfer of microRNA to protect endothelial injury. Whether administered ECFC could repopulate capillary endothelium is currently subject to debate (likely depends on mode of administration). We propose that co-operative activity of both HPP-ECFC and pro-angiogenic hematopoietic cells could potentially lead to successful engraftment in the acutely injured kidney.
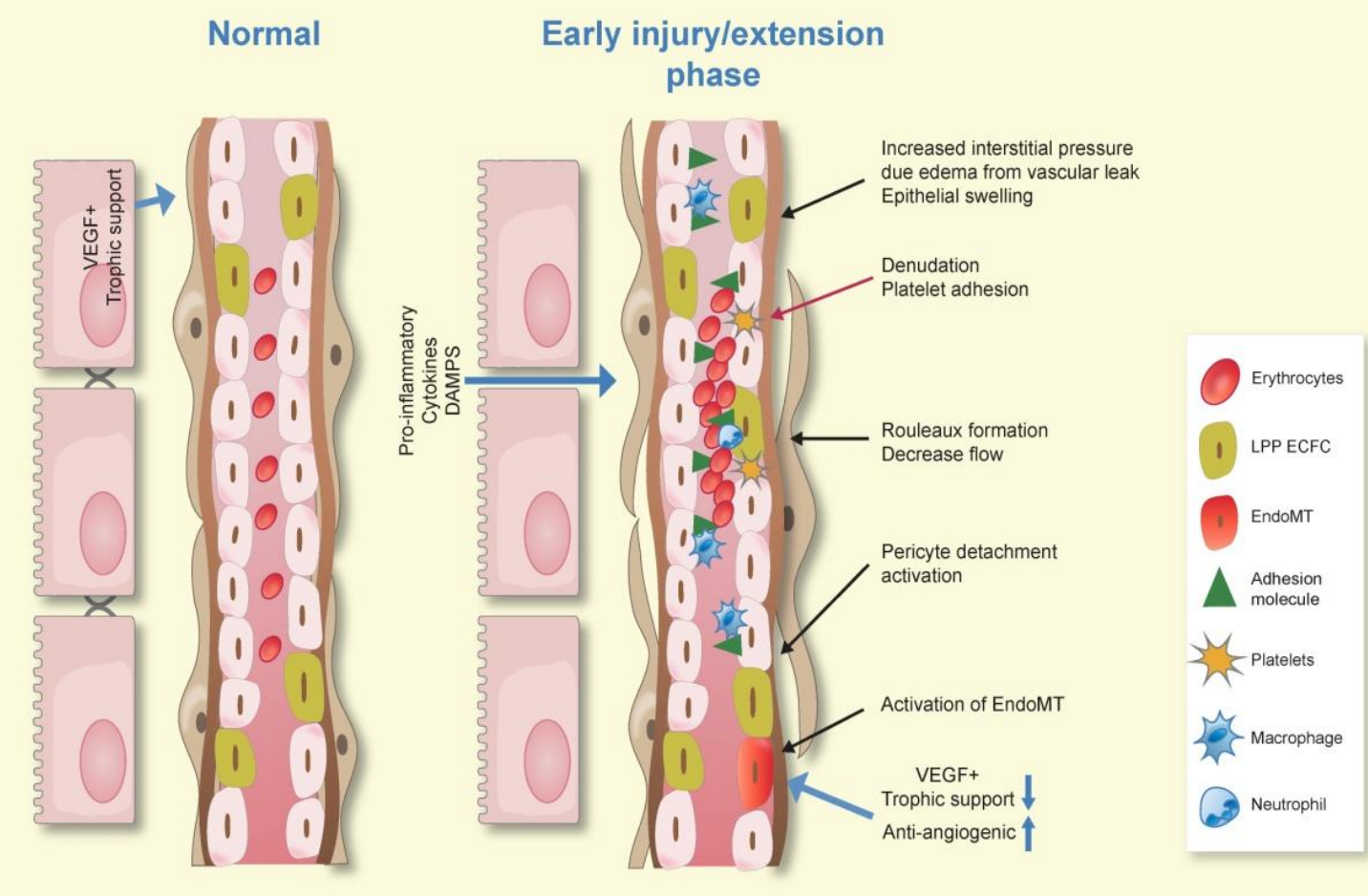

This article is protected by copyright. All rights reserved. 


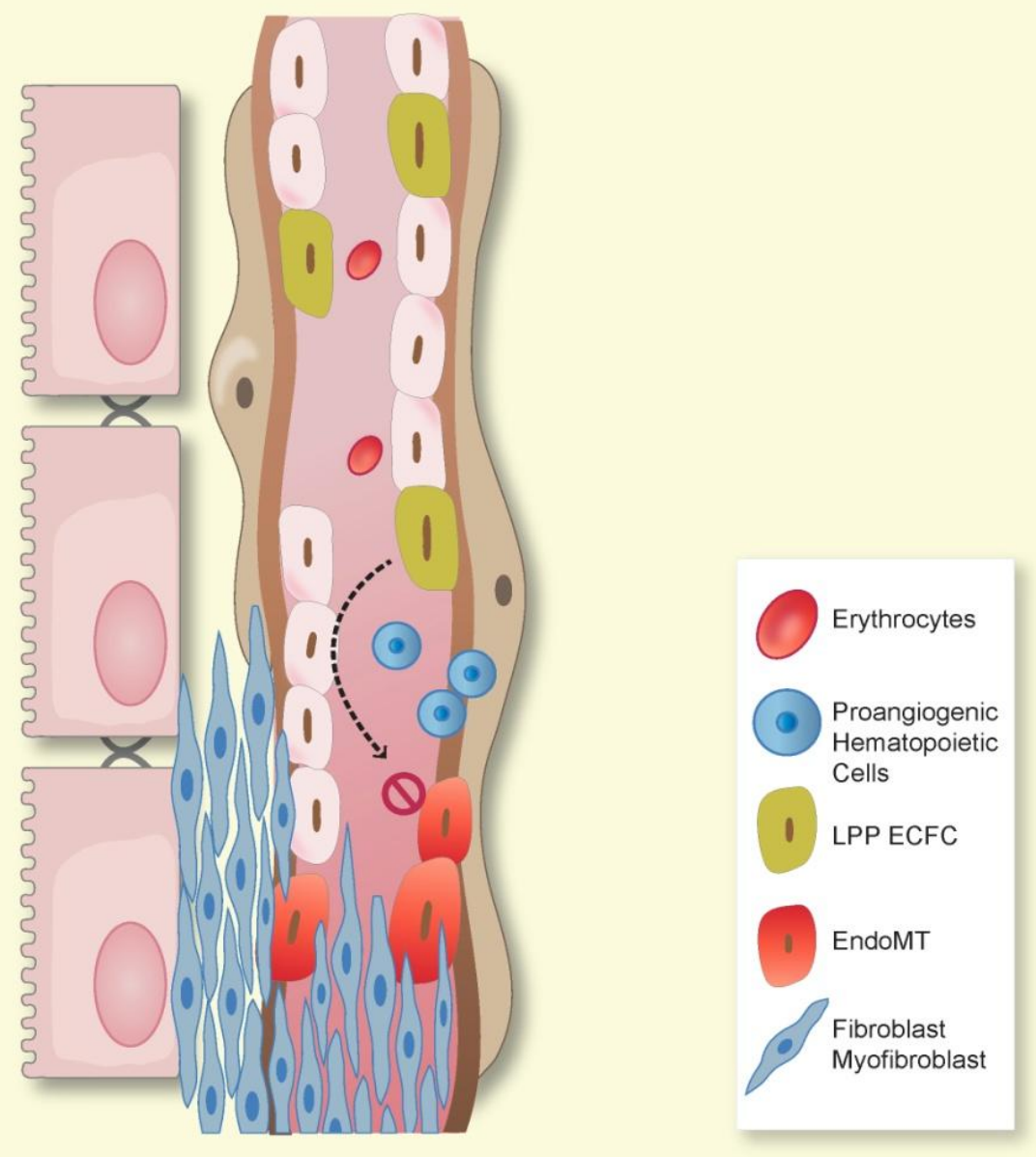

This article is protected by copyright. All rights reserved. 


\section{Markers previously used to identify EPC}

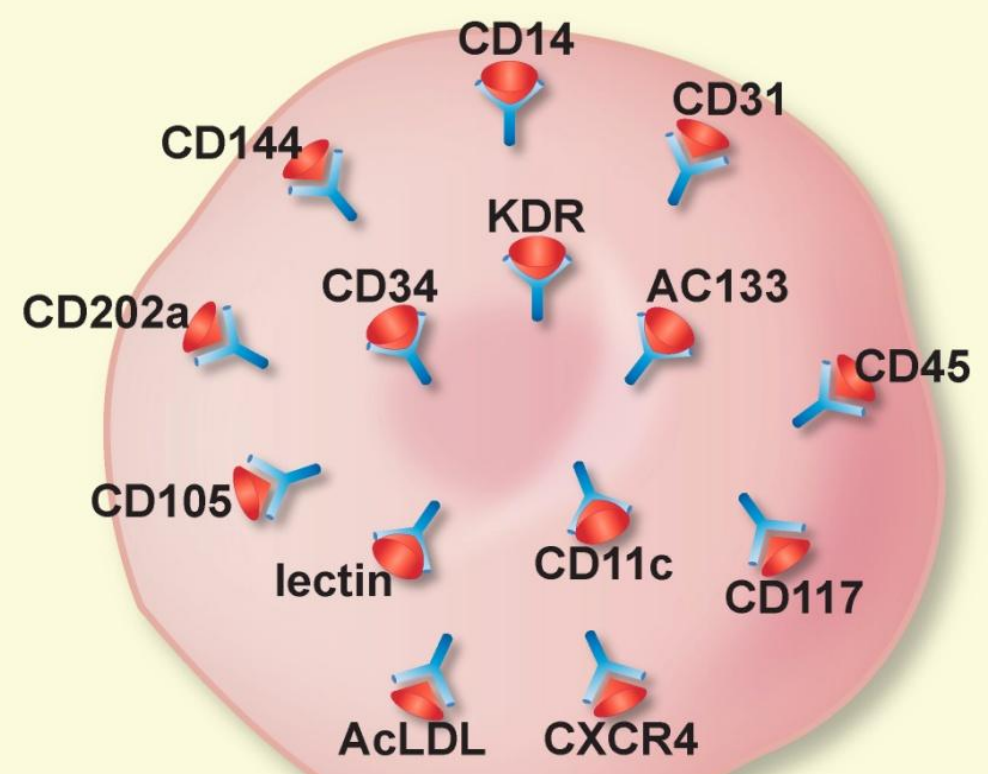

This article is protected by copyright. All rights reserved. 
A - Endothelial injury

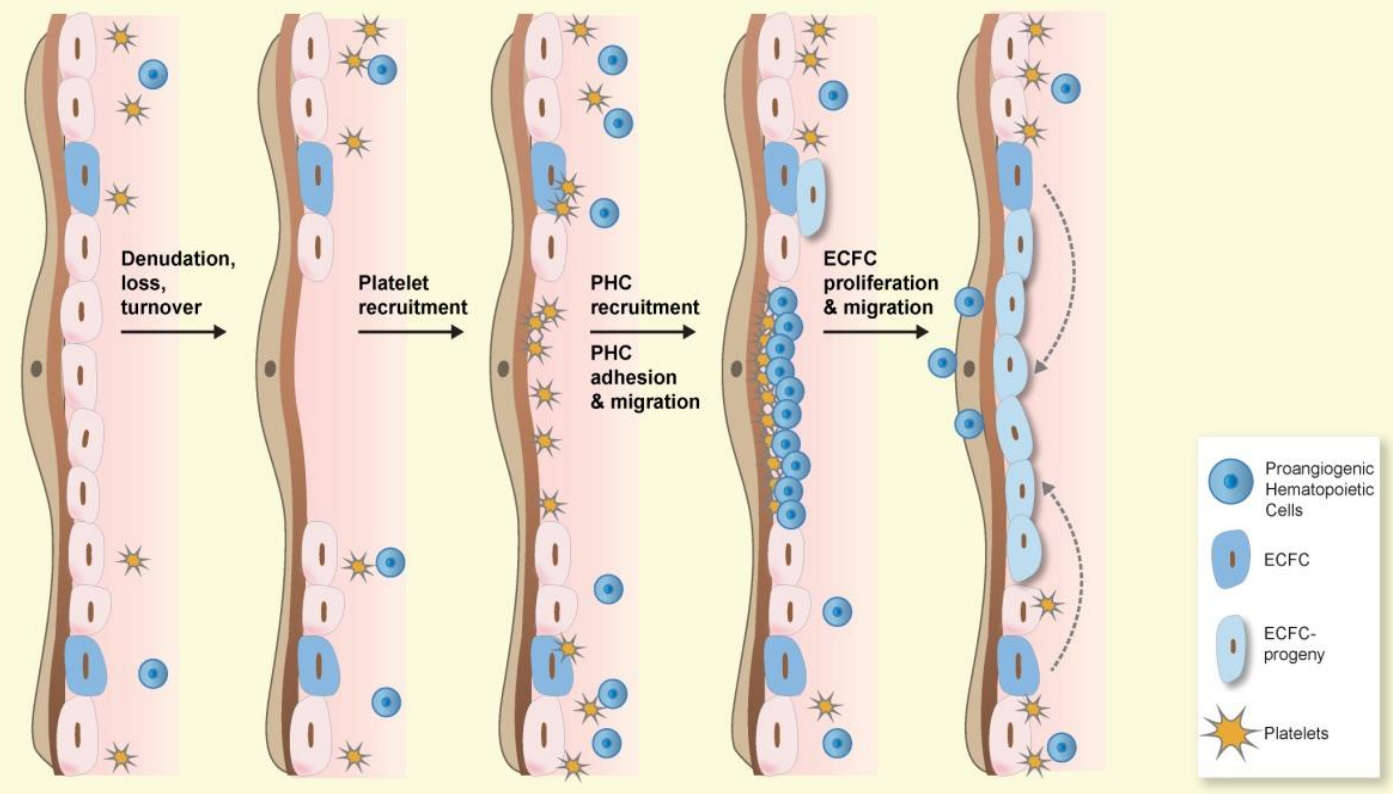

This article is protected by copyright. All rights reserved. 

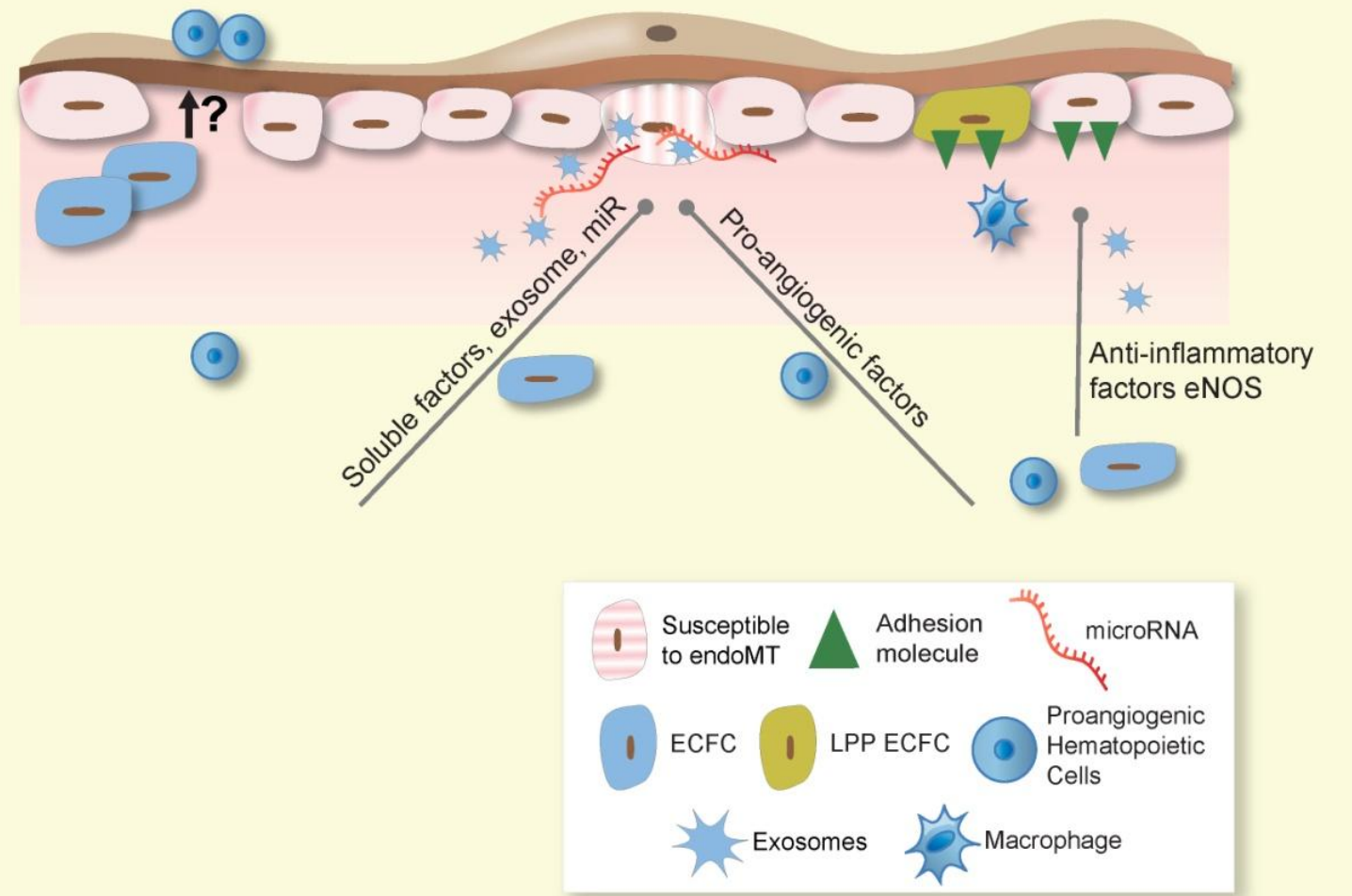

This article is protected by copyright. All rights reserved. 